\title{
The calm after the storm: Implied volatility and future stock index returns
}

\author{
Thorben Lubnau*, Neda Todorova ${ }^{\dagger}$
}

This article explores the predictive power of five implied volatility indices for subsequent returns on the corresponding underlying stock indices from January 2000 through October 2013. Contrary to previous research, very low volatility levels appear to be followed by significantly positive average returns over the next 20,40 or 60 trading days. Rolling trading simulations show that positive adjusted excess returns can be achieved when long positions in the stock indices are taken on days of very low implied volatility. This may be a hint that market inefficiencies exist in some markets, especially outside the US. The excess returns measured against a buy and hold benchmark are significant for the German and Japanese market when tested with a bootstrap methodology. The results are robust against a broad spectrum of specifications.

Keywords: Implied volatility; Technical trading; Market efficiency; Future returns

\section{Introduction}

In this study, the cross-sectional predictive ability of investor sentiment in the case of implied volatility is examined. First, the forecasting power of certain levels of five publicly available implied volatility indices regarding the future returns of the corresponding stock indices is analyzed. The economic benefit of the identified predictive power is then assessed using trading simulations and evaluation techniques from the technical analysis area. Thus, this study combines the research areas of market sentiment, technical trading and the informational content of option markets and has implications for the sustained discussion on the efficiency of financial markets.

Baker and Wurgler (2007) broadly define investor sentiment as "a belief about future cash flows and investment risks that is not justified by the facts at hand". The predictive power inherent in sentiment indicators and its economic significance have been subject of research interest for a long time (for on overview of recent literature, see for example

\footnotetext{
${ }^{*}$ Chair of Finance and Capital Market Theory, European University Viadrina, Frankfurt (Oder), Germany

${ }^{\dagger}$ Corresponding author, Griffith Business School, Griffith University, 170 Kessels Road, Nathan, Queensland 4111, Australia, Email: n.todorova@griffith.edu.au, Phone: +61 73735 7219, Fax: +61 73735 3719 .
} 
Chung, Hung and Yeh, 2012). Obviously the perception of the current market state and future expectations of investors are important information to consider during the investment decision process. However, as sentiment cannot be observed directly it must be proxied and interpreted. This leaves room for a variety of opinions and measures. Perhaps the most broadly analyzed option based sentiment indicator is the CBOE volatility index. VIX is a measure of market expectations of stock index volatility over the next 30 calendar days and is based on the prices of S\&P 500 index options. In financial literature, VIX has been referred to as the "fear gauge" of market participants, since high levels of VIX can act as an indicator of market turmoil. ${ }^{1}$ Referring to the huge popularity of the fear index, implied volatility indices were established for various international stock markets to follow the evolvement of observed option prices and reflect market expectations.

In addition to VIX being used for estimating and forecasting financial market volatility, its application as a stock market timing tool is advocated by some market participants, like Appel (2007) who suggested that extremely high levels of VIX have proven to be good opportunities to enter the market. However, relatively fewer research is dedicated to the incorporation of option market information into technical trading strategies. Most research of technical trading rules focuses on historical prices in the spot market without searching for other potential sources of information like derivatives markets (for example Brock, Lakonishok, and LeBaron, 1992; Bessembinder and Chan, 1998). A concise overview on the topic is given by Park and Irwin (2007).

Generally, the predictive power of implied volatility is subject of pervasive research interest. A huge body of literature examines the informational content of implied volatility which can be used for forecasting realized volatility (for a summary of previous research, see Poon and Granger, 2003). The findings of most of the recent papers which have overcome measurement errors and problems due to non-synchronous trading plaguing older studies like Canina and Figlewski (1993) indicate that implied volatility contains incremental forecasting power compared to historical volatility models. ${ }^{2}$ The economic significance of implied volatility has also been comprehensively assessed. For example, Konstantinidi, Skiadopoulos and Tzagkaraki (2008) examine whether the evolution of implied volatility can be forecast by studying a number of European and US implied 
volatility indices. The economic significance of the forecasts is analyzed by considering trading strategies in the CBOE volatility futures markets with the result that the existence of predictable patterns cannot be significantly economically exploited. However, most of the studies on the informational content of implied volatilities examine trading in options and not in the underlying asset (for example Poon and Pope, 2000; Ahoniemi, 2006; Chan, Jha and Kalimipalli, 2009; Goyal and Saretto, 2009). ${ }^{3}$

Comparatively fewer studies focus on the relation between implied volatility and future returns of the options' underlying assets as well as its economic significance. Banerjee, Doran and Peterson (2007) investigate the relation between stock portfolio returns from the US market and the volatility levels and innovations of the VIX from 1986 to 2005. In particular, they focus on portfolios sorted on book-to-market equity, size, and beta, establishing that the VIX variables significantly affect the returns for most portfolios, with the relation stronger for high beta portfolios. Copeland and Copeland (1999) use the one-day percentage change of VIX from its 75-day moving average from 1981 to 1997 as a signal to time the market by switching between portfolio investment strategies based on style or size. They find that following VIX timing signals may generate positive excess returns. Simon and Wiggins (2001) investigate, together with the put-call ratio and the trading index (TRIN) of NYSE, the predictive power of VIX for returns on the S\&P 500 futures contracts over 10-day, 20-day, and 30-day horizons using daily data from 1989 through 1999. They establish that these variables often have statistically and economically significant forecasting power when used as contrarian indicators, consistent with the view that periods of extreme fear in the stock market may offer profitable buying opportunities. Giot (2005) tests if high levels of implied volatility indicate oversold stock markets by dividing the VIX and VXN price history into 20 equally spaced rolling percentiles and examining the returns on the S\&P 100 and Nasdaq 100 for holding periods of 1, 5, 20 and 60 days for each of these percentiles. His results suggest that extremely high levels of VIX and VXN may signal attractive buying opportunities. Kozyra and Lento (2011), in a very short study, apply classical moving-average crossover, filter and trading-range breakout rules on the prices of DJIA, S\&P 500 and Nasdaq and the VIX prices for the period from 1999 to 2009. Overall, greater profits tend to arise when using VIX prices to establish 
trading signals, which supports the relevance of taking implied volatility into account for technical trading. All these results are overall surprising, since VIX information is publicly available and should not allow for timing profits if markets are efficient.

This study contributes to the existing research in three important ways. First, whereas previous literature considers the US market only and especially the VIX, we aim to achieve robustness by examining the relation between implied volatility and future returns for five implied volatility indices and their corresponding stock indices (two US, two European and one Asian). Therefore, the study comprises a more diverse sample of markets in terms of geographical aspects as well as market size. Our data sample comprises the period from January 2000 to October 2013 (an exception is VXN for which time series since 2001 are available) and thus includes a broad variety of market states.

Second, our regression-based approach is similar to that of Giot (2005). However, this paper's findings differ considerably from his results in that following very high levels of VIX, future returns are always significantly positive whereas negative returns are to be expected after very low volatility levels are observed. Based on recent data, our regressions reveal that returns following very high volatility levels may be positive as well as negative and vary without a clear pattern between the chosen time horizons and considered indices. Furthermore, these returns are not consistently significant. On the contrary, returns observed after very low volatility levels appear to be without exception positive and significant. To our knowledge, existent studies focus solely on high volatility levels as potential indicators signaling proper moments for taking long positions in the market. Regarding periods of low volatility, Simon and Wiggins (2001) remark in a footnote that "it is also possible that extremely low indicator levels indicate complacency and could be associated with subsequent market weakness." Our regression results suggest that very low implied volatility levels might not indicate market staleness but correctly reflect the market's expectation of a quiet bull market.

Third, to gain further insights into this somehow surprising regression-based result, a rolling trading simulation is conducted based on taking long positions in the market whenever the level of implied volatility is within its lowest $5 \%$ of a certain lookback period. A variety of financial instruments enable the implementation of such a simple 
trading strategy. For example investors can use Exchange Traded Funds (ETFs) or index futures which often belong to the most liquid derivatives of the corresponding markets. To account for the costs an investor has to bear when following a strategy like the one described, the number of signals generated and transaction costs occurring when entering or leaving the market are explicitly considered when assessing the economic significance of the trading rules. To evaluate the statistical significance of our results, a historical simulation methodology as described in Barone-Adesi et al. (1999) is employed. The trading simulation addresses two questions: Are the returns following very low volatility levels positive and is the chosen simple trading strategy capable of consistently beating the buy and hold strategy used as benchmark?

The article is structured as follows. The next section describes the data sets. The section Forecasting Properties of Implied Volatility addresses the general forecasting power of specific volatility levels of the implied volatility for subsequent returns on the corresponding stock indices. In the section Trading Simulations, the trading rules and evaluation techniques are presented. The trading results and a discussion of their economic significance is included in this section as well. The final section concludes.

\section{Data}

Daily data of five implied volatility indices and their underlying stock indices are used. In particular, two major US (VIX, VXN), two European (VDAXNEW, VCAC) and one Asian (VXJ) implied volatility indices are examined. All indices are constructed using the VIX algorithm (see Carr and Wu 2006 for a description of the computational procedure of VIX). VIX and VXN are based on the market prices on CBOE of options on the S\&P 500 and Nasdaq 100, respectively. VCAC and VDAXNEW are computed from the market prices of options on CAC 40 (France) and DAX 30 (Germany) and VXJ is based on the index options on Japan's Nikkei 225. All indices are quoted in terms of percentage points and show the annualized expected volatility of the underlying index over the next 30-day period. Data from January 2000 to October 2013 are used. The only exception is VXN for which data are available since February 2001 only. The one-month Libor acts as a 
proxy of money market interest rates for conducting trading simulations. All data are obtained from Datastream. Table 1 shows the summary statistics of the implied volatility indices and daily compound returns of the underlying stock indices.

\section{Forecasting properties of implied volatility}

This section analyzes whether general movements as well as different levels of the implied volatility indices exhibit predictive power for subsequent returns of the corresponding stock indices. ${ }^{4}$ To check whether implied volatility has a better forecasting ability in a middle-term rather than a short-term context, its predictive power is examined for stock index returns over horizons of 1, 10, 20, 40 and 60 trading days. ${ }^{5}$

To gain in-depth insights into the relation between implied volatility and future stock index returns, returns following different levels of volatility are examined. ${ }^{6}$ Similarly to Giot (2005), the implied volatility values are sorted in 20 equally spaced percentiles. Within a rolling classification approach based on the VIX and VXN observations of the last two years, Giot (2005) shows that taking long positions triggered by highest implied volatility levels generates significantly large average returns over horizons of up to 60 days in the future, whereas the returns following low implied volatility levels turn out to be consistently negative. This is in line with the practitioners' view that it is most rewarding to enter the market when investors' fear has reached extreme levels.

Using our whole sample period of 13 years and 10 months, the following regression is estimated

$$
r_{t+i}=\delta_{1} D_{t}^{1}+\delta_{2} D_{t}^{2}+\ldots+\delta_{20} D_{t}^{20}+\epsilon_{t}
$$

where $D_{t}^{j}$ with $j=1,2, . ., 20$ are dummy variables. For example, $D_{t}^{1}$ is equal to 1 when the corresponding implied volatility value on day $t$ belongs to the $5 \%$ lowest levels and 0 otherwise. In contrast, $D_{t}^{20}$ denotes a value which is higher than at least $95 \%$ of all implied volatility observations in the sample. Again, $r_{t+i}$ is the stock index return (measured in percent) observed over an $i$-day horizon after day $t$.

Table 2 shows the results for time horizons of 1, 10, 20, 40 and 60 trading days. Since the 
middle categories contain estimates with changing signs and significance and thus, have a limited explanatory power, OLS estimates and their Newey-West $t$-values are reported only for the two lowest and two highest percentiles. ${ }^{7}$

For time horizons of ten days and especially of one day, most estimates appear to be of a small magnitude and insignificant, supporting the expectation that implied volatility is a forecast indicator over the average remaining life of the index options equaling 30 calendar days. Longer time periods following highest volatility levels often exhibit negative or positive but often insignificant returns. Positive and significant returns are established only for VXJ for 40-days ahead and for VXN for 20- and 40-days ahead. In contrast, considering horizons of 20, 40 and 60 days, it becomes obvious that returns following lowest volatility levels in the sample turn out to be consistently positive across all indices. Furthermore, they provide the highest $t$-values and exhibit, compared to other percentiles, the most consistent behavior.

To our knowledge, there is not much to be found in literature about the forecasting performance of extremely low implied volatility levels. Research focuses mostly on high volatility levels since they are associated with falling prices and thus with higher expected returns. It is less clear how the market behaves when or after implied volatility is low. Simon and Wiggins (2001) note that extremely low levels may indicate complacency and subsequent market weakness. Moreover, they report, referring to untabulated results, that dummy variables taking the value of one when the indicator variables are in their lowest deciles, and zero otherwise, seldom have significant forecasting power. Generally, due to the mean-reverting feature of financial market volatility, it may be expected that a period of low volatility will be followed by a rise which itself is often associated with declining asset prices. This so-called leverage effect is one of the often mentioned stylized facts of financial time series (for example Cont, 2001). Furthermore, in the contest of historical volatility, however, Campbell and Hentschel (1992) argue that "no news are good news" and Maheu and McCurdy (2000) associate bull markets with low volatility. In the case of stocks, Blitz and van Vliet (2007) argue that low-volatility securities may have significantly higher returns than high-volatility shares.

Overall, our regression results surprisingly suggest that low volatility implied in index 
options may not compulsorily be an indicator of market staleness. On the contrary, low volatility seems to be followed by medium-term positive and significant average returns indicating that low implied volatility may be just correctly expressing a prevailing expectation by investors that no market turbulence is in sight. In the following, we seek for deeper insights into the nature and economic significance of this surmise.

\section{Trading simulations}

As low levels of implied volatility seem to be followed by significantly positive returns on the respective stock index, it is necessary to test whether it is possible to exploit this finding in terms of economic profit. Specific rules are set up based on the levels of a volatility index. Then, trading simulations are run according to these rules to test the significance of the results with a historical simulation methodology. In the following, holding periods of 10,20, 40 and 60 days are considered. Due to the insignificant results in the regression-based analysis, the alternative of holding the underlying index for one day only is disregarded.

\subsection{Trading rules}

The investment decision process is as follows. A lookback period of $l b$ days with $l b=$ $100,200,300$ is used. The volatility index values of the lookback period are sorted in ascending order and the price marking the lowest $5 \%$ percentile is used as threshold. The magnitude of the current day's volatility index is compared to this threshold and generates a buy signal if it is equal or less than the threshold. ${ }^{8}$

After setting up the trading rule, a specific strategy is defined to evaluate the economic significance of the trades. A long position in the index is taken for the specified holding period whenever a buy signal is generated. During the holding period, new signals are not considered and the investor's position remains unchanged. The days outside the holding periods of buy signals qualify as money market periods. That means that whenever a buy signal is not in effect, the proceeds are invested in the money market. Therefore, the index returns are earned when buy signals are in effect and the current money market 
rates are earned the rest of the time. Evaluation benchmark of both strategies is a simple buy and hold strategy. Even though trading strategies may be able to detect periods of above average returns, they come at a cost. Whenever a signal is generated, a transaction occurs as the investor goes long the market. Another transaction takes place when the specified holding period comes to an end and the long position is liquidated. In this study, transaction costs are taken into account by assuming costs of $0.1 \%$ per trade. The success of each strategy is measured by looking at the adjusted excess return (AER) which corresponds to the accumulated return after transaction costs and deducting the return one would receive by merely buying and holding the respective stock index. The AER is calculated as follows

$$
\mathrm{AER}_{M M}=\sum r_{b u y}+\sum r_{s e l l / M M}-\mathrm{TAC}-r_{b \& h}
$$

Here, $T A C$ stands for transaction costs and $r_{b \& h}$ is the return of a buy and hold strategy.

\subsection{Simulations}

To test the statistical significance of the results, we use a historical simulation methodology close to the one presented in Barone-Adesi et al. (1999). This approach works like the bootstrap whose basic form is outlined in Efron and Tibshirani (1986). In the field of technical analysis, bootstrapping is widely popular since the seminal paper by Brock, Lakonishok, and LeBaron (1992) was published (for example Levich and Thomas, 1993, Bessembinder and Chan, 1998, Lubnau and Todorova, 2012). The bootstrap is a simulation-based testing approach which offers the advantage of not making any assumptions about the distribution of the tested data.

To implement the bootstrap methodology, a given number of bootstrap samples are generated following a fixed procedure. Different resampling strategies are possible and can be easily implemented (for a number of alternative approaches, see Brock, Lakonishok, and LeBaron, 1992). To preserve the well documented stylized facts of volatility clustering and the asymmetric structure of volatility, we opt for an asymmetric GARCH model like the GJR-GARCH of Glosten et al. (1993). ${ }^{9}$ Using the original time series of the index 
and the respective volatility index, we estimate parameters according to the following $\operatorname{ARMA}(1,1)$-mean and variance equations.

$$
\begin{aligned}
r_{t} & =\mu r_{t-1}+\theta \epsilon_{t-1}+\epsilon_{t}, \quad \epsilon_{t} \sim N\left(0, \sigma_{t}^{2}\right) \\
\sigma_{t}^{2} & =\omega+\alpha \epsilon_{t-1}^{2}+\lambda I_{\epsilon_{t-1}<0} \epsilon_{t-1}^{2}+\beta \sigma_{t-1}^{2} .
\end{aligned}
$$

In the variance equation, $I$ is an indicator function that is unity whenever $\epsilon_{t-1}$ is negative and zero otherwise. Instead of resampling the original returns, the standardized residu-

als $\frac{\epsilon_{t}}{\sigma_{t}}$ are used. By randomly drawing with replacement and plugging the standardized residuals multiplied by the current volatility into the model equations, we generate new time series of returns and prices. To test the significance of the trading results, 1,000 bootstrap samples are created.

Afterwards, the trading rules described above are applied to the bootstrap samples and the various statistics are calculated. That means that there are returns for buy and sell periods, adjusted profits and the standard deviations of the buy and sell return series of each bootstrap sample and each trading strategy. By comparing these results with those of the original series, it is possible to derive a simulated $p$-value or approximated achieved significance level for each and every statistic. As in Efron and Tibshirani (1993), the achieved significance level is computed as

$$
\widehat{A S L}=\frac{\#\left\{t\left(S^{* i}\right) \geq t(S)\right\}}{B}, \quad i=1, \ldots, B, \quad B=1,000 .
$$

The simulated $p$-value is the number of bootstrap samples whose value concerning the statistic of interest is more extreme than the value of that statistic for the original data. It should be noted that whenever the statistic is expected to be lower for the original series than for the bootstrap samples $1-\widehat{A S L}$ yields the $p$-value.

\subsection{Results}

Trading results are presented in tables 3 to 5 . The first column of the tables specifies the holding period used in the specific trading simulation followed by the number of buy 
signals. In columns 3 and 4 , the sum of returns on buy days and the sum of returns on sell days are presented. Column 5 reports the AER. Following are the numbers of buy and sell days. The last two columns of tables 3 to 5 show the standard deviations of the buy returns and the sell returns. The achieved significance level $\widehat{A S L}$ is reported in parentheses below the respective statistic. For the purpose of robustness, the trading simulations are conducted on the basis of rolling lookback periods of 100, 200 and 300 trading days.

The trading simulations address two questions. The first one is whether the returns following very low volatility levels are positive. If yes, this would indicate that low volatility levels are indeed capable of forecasting subsequent bull markets. Second, looking at the overall performance of the trading rules, it can be assessed whether the chosen simple trading strategy may beat the corresponding market. As the volatility indices are publicly available without any further cost, this would hint towards market inefficiency as not all historical data is incorporated into current prices. Positive adjusted excess returns can therefore be interpreted as results of successful trading strategies based solely on historic data in comparison to a benchmark investor who persues a buy and hold strategy.

Addressing the first question, the analysis of the sum of returns on buy days casts doubts whether the lowest volatility levels observed over the last 100, 200 or 300 trading days may consistently predict positive consequent returns over the next 10, 20, 40 and 60 days. Some of the indices included in our sample, like the CAC and Nikkei, experienced serious bear markets during the periods under consideration. The reported results indicate that timing the market based on very low volatility with the specified trading rule is not capable of avoiding bear periods completely so that the overall return on buy days may turn out to be negative. However, a closer look at the distinct forecast horizons reveals that in 12 out of 15 cases, the realized returns over the next 20 trading days appear to be positive, with two of the three negative values coming from the French market. This is widely conform to the nature of implied volatility indices referring to the average underlying asset's performance over the next 30 calendar days and confirms the previously identified potential predictive power of low volatility, albeit the positive buy day returns are not significant when tested with the historical simulation setup. However, achieving 
positive returns on buy days is only part of a succesful trading strategy, as it is equally important to shy away from falling markets. Therefore, even if buy day returns are not significant, it is still possible to have a significantly profitable trading strategy.

In this respect, the simulated long-money market strategy shows positive AERs for all combinations but for the VXN with lookback periods of 200 and 300 days, one combination of the Nikkei and four combinations of VIX. Whereas the 20, 40 and 60-day holding periods are closer to the forecasting horizon of the investor sentiment proxies of 30 days, the 10day holding periods may be influenced by short-term factors not reflected in these proxies. Nevertheless, the results indicate that investors following the strategies described in this paper detected periods of above average returns quite well with the generated buy signals. Considering the magnitude of the AERs, there seems to be a clear divide between US and non-US markets, as the European and Japanese markets often show AERs of $40 \%$ or more. The US markets either have negative AERs or stay in a range of $5 \%$ to $15 \%$.

Over and above, the bootstrap tests show mixed results. Significance is documented most consistently for the DAX and Nikkei and to a lesser extent with the other indices. Most notably, the AERs for the DAX with lookback periods of 100 and 300 days are significant at the $5 \%$-level in 7 out of 8 combinations tested. Overall, while there are a number of cases with results significant at the $5 \%$, none of these is significant at the $1 \%$ level.

\section{Conclusion}

In this study, the relation between five implied volatility indices and the future returns of their underlying stock indices as well as its economic exploitability are examined. In a first step, an approach similar to that of Giot (2005) is adopted. Giot (2005) divides recent implied volatility history into 20 equally spaced percentiles and examines the returns following each of these percentiles. He argues that extremely high levels of implied volatility may be used for identifying profitable buying opportunities. The current study cannot conclusively confirm this result. However, taking daily observations of almost 14 years into account, low levels of volatility are found to be followed by significantly positive 
rates of return.

Unlike the findings of previous studies, periods of extremely low levels of volatility may be indicative of attractive times to enter the market. This is rather in line with the general notion that markets tend to rise in calm periods and fall when volatility is high. Accordingly, opposite to extant studies, the focus is set on the predictive ability of low volatility levels and trading simulations are conducted to assess the economic significance and robustness of this finding.

The simple trading rules exhibit for the most part strong positive adjusted excess returns against a buy and hold strategy for CAC, DAX and Nikkei whereas the results for the US indices are mixed and in general weaker than for the other markets. This gives hint to a possibility to outperform the underlying stock indices when periods of low implied volatility are used for identifying temporal patterns. Furthermore, the accumulated returns after transaction costs are significant in most cases for the DAX and Nikkei and for some specifications of the Nasdaq when tested with the bootstrap methodology. Overall the results indicate a discrepancy between US and non-US markets concerning weak-form efficiency. The magnitude of the AERs in Germany, France and Japan could mean that prices do not fully incorporate all available historical information, whereas the US markets seem to be efficient given our simple trading strategy.

\section{Appendix A: Tables}

[insert Table 1]

[insert Table 2]

[insert Table 3]

[insert Table 4]

[insert Table 5] 


\section{Notes}

${ }^{1}$ See Whaley (2000) and Whaley (2009) for a detailed description and analysis of historical data of VIX.

${ }^{2}$ However, there is also newer research indicating that models based on realized volatility may outperform option-based models when forecasting volatility (for example Koopman, Jungbacker and Hol, 2005).

${ }^{3}$ Furthermore, there is a restricted number of studies which apply classical technical trading rules based on other information inherent in derivatives markets like for example open interest (see Charlebois and Sapp, 2007, Lubnau and Todorova, 2012).

${ }^{4}$ Overall aim of the study is to examine the ex-ante predictive power of implied volatility. However, we estimated regressions comprising contemporaneous volatility and stock index level innovations as well and found the coefficients to be negative and significant, conform to the well documented negative contemporaneous relation between volatility and returns.

${ }^{5}$ Taking into account other horizons (results not tabulated) supports the presented conclusions.

${ }^{6}$ In earlier drafts of this paper, a regression analysis following the approach of Simon and Wiggins (2001) was conducted resulting in only minor forecasting power of implied volatility inovations for future index returns. Extending the regression of Simon and Wiggins (2001) to an ARMA model with GARCH effects with the time-varying volatility of the index appearing in the equation for the mean leads to significant and consistent improvement of the results. We thank the editor for this suggestion. Since the study focuses on the predictive power of specific volatility levels, these results are omitted to save space but are available upon request.

${ }^{7}$ The remaining results are available on request.

${ }^{8}$ Results for a threshold of $10 \%$ seem to be inferior to those of the $5 \%$ threshold, indicating that positive returns can be associated with the lowest levels of volatility only.

${ }^{9}$ We thank the editor for kindly pointing this out.

\section{References}

Ahoniemi, K. (2006). Modeling and forecasting implied volatility: An econometric analysis of the VIX index. Working paper, Helsinki School of Economics.

Appel, G. (2007). Technical Analysis - Power tools for active investors. New Jersey: FT Press.

Baker, M., \& Wurgler, J. (2007). Investor sentiment in the stock market. Journal of Economic Perspectives, 21, 129-151. 
Banerjee, P. S., Doran, J. S., \& Peterson, D. R. (2007). Implied volatility and future portfolio returns. Journal of Banking \& Finance, 31, 3183-3199.

Barone-Adesi, G., Giannopoulos, K., \& Vosper, L. (1999). VaR without correlations for portfolios of derivative securities. Journal of Futures Markets, 19, 583-602

Bessembinder, H., \& Chan, K. (1998). Market efficiency and the returns to technical analysis. Financial Management, 27, 5-17.

Blitz, D. C., \& van Vliet, P. (2007). The volatility effect: Lower risk without lower return. Journal of Portfolio Management, 34, 102-113.

Bluhm, H. H., \& Yu, J. (2000). Forecasting volatility: Evidence from the German stock market. In P. Franses and M. McAleer (Eds.), Modelling and Forecasting Financial Volatility (pp. 173-193).

Brock, W., Lakonishok, J., \& LeBaron, B. (1992). Simple technical trading rules and the stochastic properties of stock returns. The Journal of Finance, 47, 1731-1764.

Campbell, J. Y. \& Hentschel, L. (1992). No news is good news: An asymmetric model of changing volatility in stock returns. Journal of Financial Economics, 31, 281-318.

Canina, L., \& Figlewski, S. (1993). The informational content of implied volatility. Review of Financial Studies, 6, 659-681.

Carr, P., \& Wu, L. (2006). A tale of two indices. Journal of Derivatives, 13, 13-29.

Chan, W., Jha, R., \& Kalimipalli, M. (2009). The economic value of using realized volatility in forecasting future implied volatility. Journal of Financial Research, 32, 231-259.

Charlebois, M., \& Sapp, S. (2007). Temporal patterns in foreign exchange returns. Journal of Money, Credit, and Banking, 39, 443-470.

Chung, S.-H., Hung, C.-H., \& Yeh, C.-Y. (2012). When does investor sentiment predict stock returns? Journal of Empirical Finance, 19, 217-224.

Cont, R. (2001). Empirical properties of asset returns: Stylized facts and statistical issues. Quantitative Finance, 1, 223-236. 
Copeland, M., \& Copeland, T. (1999). Market timing: Style and size rotation using the VIX. Financial Analysts Journal, 55, 73-81.

Efron, B., \& Tibshirani, R. (1986). Bootstrap methods for standard errors, confidence intervals, and other measures of statistical accuracy. Statistical Science, 1, 54-75.

Efron, B., \& Tibshirani, R. (1993). An introduction to the bootstrap. New York: Chapman and Hall.

Giot, P. (2005). Relationships between implied volatility indices and stock index returns. Journal of Portfolio Management, 31, 92-100.

Glosten, L., Jagannathan, R., \& Runkle, D. (1993). On the relation between the expected value and the volatility of the nominal excess return on stocks. Journal of Finance, 48, $1779-1801$

Goyal, A., \& Saretto, A. (2009). Cross-section of option returns and volatility. Journal of Financial Economics, 94, 310-326.

Konstantinidi, E., Skiadopoulos, G., \& Tzagkaraki, E. (2008). Can the evolution of implied volatility be forecasted? Evidence from European and US implied volatility indices. Journal of Banking \& Finance, 32, 2401-2411.

Koopman, S. J., Jungbacker, B., \& Hol, E. (2005). Forecasting daily variability of the S\&P 100 stock index using historical, realized and implied volatility measurements. Journal of Empirical Finance, 12, 445-475.

Kozyra, J., \& Lento, C. (2011). Using VIX data to enhance technical trading signals. Applied Economics Letters, 18, 1367-1370.

Levich, R., \& Thomas, L. (1993). The significance of technical trading-rule profits in the foreign exchange market: A bootstrap approach. Journal of International Money and Finance, 12, 451-474.

Lubnau, T., \& Todorova, N. (2011). Technical trading with open interest: Evidence from the German market. Applied Financial Economics, 22, 791-809. 
Maheu, J. M., \& McCurdy, T. H. (2000). Identifying bull and bear markets in stock returns. Journal of Business \& Economic Statistics, 18, 100-112.

Park, C.-H., \& Irwin, S. (2007). What do we know about the profitability of technical analysis? Journal of Economic Surveys, 21, 786-826.

Poon, S.-H., \& Granger, C. W. J. (2003). Forecasting volatility in financial markets: A review. Journal of Economic Literature, 41, 478-539.

Poon, S. H., \& Pope, P. F. (2000). Trading volatility spreads: A test of index option market efficiency. European Financial Management Journal, 6, 235-260.

Simon, D. P., \& Wiggins III, R. A. (2001). S\&P futures returns and contrary sentiment indicators. The Journal of Futures Markets, 21, 447-462.

Whaley, R. E. (2000). The investor fear gauge. Journal of Portfolio Management, 26, $12-17$.

Whaley, R. E. (2009). Understanding the VIX. Journal of Portfolio Management, 35, $98-105$. 


\section{Appendix: Tables}

Table 1: Summary statistics

\begin{tabular}{lrrrrr}
\hline \multicolumn{1}{c}{ VCAC } & VDAXNEW & VIX & VXN & VXJ \\
\hline Summary & statistics for implied volatility indices & \\
Mean & 24.145 & 25.184 & 21.529 & 27.634 & 26.427 \\
SD & 9.376 & 10.382 & 9.125 & 13.007 & 9.386 \\
Min & 9.24 & 11.65 & 9.89 & 12.03 & 11.52 \\
Max & 78.05 & 83.23 & 80.86 & 80.64 & 91.45 \\
Skewness & 1.567 & 1.624 & 1.961 & 1.284 & 2.451 \\
Kurtosis & 3.267 & 2.958 & 6.137 & 0.892 & 9.531 \\
JB & 0.000 & 0.000 & 0.000 & 0.000 & 0.000 \\
Summary & statistics of the index daily returns (in percent) \\
Mean & -0.009 & 0.008 & 0.005 & 0.010 & -0.008 \\
SD & 1.542 & 1.589 & 1.322 & 1.759 & 1.580 \\
Min & -9.472 & -8.875 & -9.470 & -11.115 & -12.111 \\
Max & 10.595 & 10.797 & 10.957 & 11.849 & 13.235 \\
Skewness & 0.027 & -0.005 & -0.172 & 0.016 & -0.422 \\
Kurtosis & 4.626 & 4.242 & 7.619 & 4.651 & 6.265 \\
JB & 0.000 & 0.000 & 0.000 & 0.000 & 0.000 \\
\hline
\end{tabular}

Note: Summary statistics of each of the implied volatility indices and of the underlying stock indices and their daily returns are presented. VIX, VXN, VXJ, VDAXNEW and VCAC denote the implied volatility indices based on the market prices of index options on S\&P 500, Nasdaq 100, Nikkei 225, DAX 30 and CAC 40, respectively. Time period is January 1 , 2000 to October 31, 2013 except for Nasdaq (February 1, 2001 to October 31, 2013). JB stands for the $p$-values of the Jarque-Bera test statistics with the null hypothesis that the variable is normally distributed. 
Table 2: Realized returns categorized by volatility levels

\begin{tabular}{|c|c|c|c|c|c|c|c|c|c|c|}
\hline & \multicolumn{2}{|c|}{1 Day } & \multicolumn{2}{|c|}{10 Days } & \multicolumn{2}{|c|}{20 Days } & \multicolumn{2}{|c|}{40 Days } & \multicolumn{2}{|c|}{60 Days } \\
\hline & $\begin{array}{c}\text { OLS } \\
\text { coeff. }\end{array}$ & $\begin{array}{c}t- \\
\text { value }\end{array}$ & $\begin{array}{l}\text { OLS } \\
\text { coeff. }\end{array}$ & $\begin{array}{c}t- \\
\text { value }\end{array}$ & $\begin{array}{c}\text { OLS } \\
\text { coeff. } \\
\text { VXJ } \\
\end{array}$ & $\begin{array}{c}t- \\
\text { value }\end{array}$ & $\begin{array}{c}\text { OLS } \\
\text { coeff. }\end{array}$ & $\begin{array}{c}t- \\
\text { value }\end{array}$ & $\begin{array}{c}\text { OLS } \\
\text { coeff. }\end{array}$ & $\begin{array}{c}t- \\
\text { value }\end{array}$ \\
\hline$\delta_{1}$ & 0.138 & 2.25 & 0.730 & 2.24 & 0.929 & 2.99 & 2.904 & 3.40 & 5.455 & 5.25 \\
\hline$\delta_{2}$ & 0.053 & 0.81 & 0.912 & 7.80 & 1.985 & 6.68 & 2.050 & 7.71 & 2.715 & 5.49 \\
\hline$\delta_{19}$ & 0.017 & 0.09 & -0.546 & -1.49 & 0.223 & 0.38 & 0.036 & 0.04 & -0.947 & -1.19 \\
\hline$\delta_{20}$ & 0.064 & 0.21 & 0.284 & 0.75 & $\begin{array}{l}0.986 \\
\text { VCAC } \\
\end{array}$ & 1.30 & 2.477 & 1.91 & 4.369 & 1.46 \\
\hline$\delta_{1}$ & 0.044 & 0.93 & 0.816 & 4.13 & 1.555 & 8.21 & 2.895 & 8.56 & 3.740 & 29.49 \\
\hline$\delta_{2}$ & 0.061 & 0.99 & -0.005 & -0.02 & 0.175 & 0.90 & 1.472 & 12.85 & 2.456 & 8.61 \\
\hline$\delta_{19}$ & -0.232 & -1.14 & -0.917 & -1.60 & -1.515 & -2.63 & -0.213 & -0.58 & 0.428 & 0.61 \\
\hline$\delta_{20}$ & 0.334 & 1.43 & 0.801 & 1.60 & 1.149 & 1.53 & -1.134 & -1.19 & -1.315 & -1.33 \\
\hline \multicolumn{11}{|c|}{ VDAXNEW } \\
\hline$\delta_{1}$ & 0.061 & 1.23 & 0.493 & 2.30 & 0.892 & 5.20 & 3.455 & 22.79 & 4.475 & 21.26 \\
\hline$\delta_{2}$ & 0.048 & 0.86 & 0.472 & 2.19 & 1.251 & 4.68 & 2.118 & 7.19 & 3.405 & 9.79 \\
\hline$\delta_{19}$ & -0.220 & -1.16 & -0.947 & -1.29 & -0.673 & -0.85 & 0.657 & 0.72 & 3.565 & 5.98 \\
\hline$\delta_{20}$ & 0.191 & 0.70 & 0.526 & 1.17 & $\begin{array}{c}0.798 \\
\text { VIX } \\
\end{array}$ & 1.19 & -0.868 & -1.28 & -2.586 & -2.05 \\
\hline$\delta_{1}$ & -0.010 & -0.27 & 0.103 & 0.68 & 0.174 & 0.76 & 0.639 & 9.55 & 1.181 & 6.46 \\
\hline$\delta_{2}$ & -0.010 & -0.26 & 0.084 & 0.49 & 0.449 & 2.01 & 1.017 & 2.86 & 1.208 & 2.01 \\
\hline$\delta_{19}$ & 0.138 & 0.87 & 0.519 & 1.11 & 0.653 & 1.20 & 2.159 & 6.49 & 4.034 & 11.31 \\
\hline$\delta_{20}$ & 0.071 & 0.28 & -0.177 & -0.25 & $\begin{array}{l}0.134 \\
\text { VXN } \\
\end{array}$ & 0.13 & 0.223 & 0.20 & 1.139 & 0.39 \\
\hline$\delta_{1}$ & 0.034 & 0.57 & 0.190 & 1.19 & $\overline{0.619}$ & 4.58 & 2.119 & 9.11 & 2.386 & 11.85 \\
\hline$\delta_{2}$ & -0.041 & -0.65 & -0.128 & -0.53 & 0.291 & 1.26 & 0.553 & 3.86 & 0.893 & 3.64 \\
\hline$\delta_{19}$ & -0.172 & -0.77 & -1.738 & -2.41 & -3.127 & -2.43 & -2.357 & -1.14 & -1.946 & -0.80 \\
\hline$\delta_{20}$ & 0.163 & 0.54 & 0.700 & 0.86 & 2.098 & 2.58 & 3.715 & 3.38 & 1.650 & 1.19 \\
\hline
\end{tabular}

Note: For every forward-looking horizon, the estimated OLS coefficients for the regression

$$
r_{t+i}=\delta_{1} D_{t}^{1}+\delta_{2} D_{t}^{2}+\ldots+\delta_{20} D_{t}^{20}+\epsilon_{t}
$$

and the corresponding $t$-values based on Newey-West standard errors are given. $r_{t+i}(i=1,10,20,40)$ denote the stock index returns (in percent) observed over an $i$-day horizon after day $t . D_{t}^{j} j=1,2, \ldots, 20$ are dummy variables denoting whether the implied volatility value of day $t$ belongs to the $i$ th out of 20 equally spaced percentiles. To save space, only the coefficients $\delta_{1}, \delta_{2}, \delta_{19}$ and $\delta_{20}$ are tabulated. 
Table 3: Trading Results with VCAC (France) and VDAXNEW (Germany)

\begin{tabular}{|c|c|c|c|c|c|c|c|c|}
\hline $\mathrm{HP}$ & Sig. & $\sum r_{b u y}$ & $\sum r_{s e l l}$ & $A E R$ & $N_{\text {buy }}$ & $N_{\text {sell }}$ & $\sigma_{\text {buy }}$ & $\sigma_{\text {sell }}$ \\
\hline \multicolumn{9}{|c|}{ VCAC 100 days } \\
\hline 10 & 95 & $\begin{array}{r}-0.24886 \\
(0.874)\end{array}$ & $\begin{array}{r}0.35110 \\
(0.992)\end{array}$ & $\begin{array}{r}0.27631 \\
(0.198)\end{array}$ & 945 & 2490 & $\begin{array}{r}0.01074 \\
(0.632)\end{array}$ & $\begin{array}{r}0.00009 \\
(0.519)\end{array}$ \\
\hline 20 & 67 & $\begin{array}{r}-0.09773 \\
(0.784)\end{array}$ & $\begin{array}{r}0.30826 \\
(0.997)\end{array}$ & $\begin{array}{r}0.44059 \\
(0.176)\end{array}$ & 1323 & 2112 & $\begin{array}{r}0.01149 \\
(0.569)\end{array}$ & $\begin{array}{r}0.00008 \\
(0.823)\end{array}$ \\
\hline 40 & 40 & $\begin{array}{c}0.07184 \\
(0.698)\end{array}$ & $\begin{array}{r}0.27366 \\
(0.978)\end{array}$ & $\begin{array}{r}0.62957 \\
(0.158)\end{array}$ & 1565 & 1870 & $\begin{array}{r}0.01178 \\
(0.635)\end{array}$ & $\begin{array}{r}0.00009 \\
(0.519)\end{array}$ \\
\hline 60 & 31 & $\begin{array}{r}-0.14025 \\
(0.853)\end{array}$ & $\begin{array}{r}0.24763 \\
(0.961)\end{array}$ & $\begin{array}{r}0.40945 \\
(0.202)\end{array}$ & 1855 & 1580 & $\begin{array}{r}0.01226 \\
(0.639)\end{array}$ & $\begin{array}{r}0.00008 \\
(0.969)\end{array}$ \\
\hline \multicolumn{9}{|c|}{ VCAC 200 days } \\
\hline 10 & 76 & $\begin{array}{r}-0.13274 \\
(0.848)\end{array}$ & $\begin{array}{r}0.35622 \\
(0.949)\end{array}$ & $\begin{array}{r}0.40953 \\
(0.166)\end{array}$ & 755 & 2580 & $\begin{array}{r}0.01045 \\
(0.533)\end{array}$ & $\begin{array}{r}0.00009 \\
(0.493)\end{array}$ \\
\hline 20 & 49 & $\begin{array}{r}0.34933 \\
(0.151)\end{array}$ & $\begin{array}{r}0.33320 \\
(0.944)\end{array}$ & $\begin{array}{r}0.92258 \\
(0.082)\end{array}$ & 964 & 2371 & $\begin{array}{r}0.01062 \\
(0.588)\end{array}$ & $\begin{array}{r}0.00008 \\
(0.627)\end{array}$ \\
\hline 40 & 31 & $\begin{array}{r}0.14355 \\
(0.538)\end{array}$ & $\begin{array}{r}0.30716 \\
(0.934)\end{array}$ & $\begin{array}{r}0.72676 \\
(0.115)\end{array}$ & 1205 & 2130 & $\begin{array}{r}0.01103 \\
(0.632)\end{array}$ & $\begin{array}{r}0.00008 \\
(0.764)\end{array}$ \\
\hline 60 & 24 & $\begin{array}{r}0.07550 \\
(0.673)\end{array}$ & $\begin{array}{r}0.27696 \\
(0.952)\end{array}$ & $\begin{array}{r}0.64252 \\
(0.126)\end{array}$ & 1435 & 1900 & $\begin{array}{r}0.01186 \\
(0.542)\end{array}$ & $\begin{array}{r}0.00008 \\
(0.805)\end{array}$ \\
\hline \multicolumn{9}{|c|}{ VCAC 300 days } \\
\hline 10 & 67 & $\begin{array}{r}-0.27251 \\
(0.976)\end{array}$ & $\begin{array}{r}0.33982 \\
(0.973)\end{array}$ & $\begin{array}{r}0.17810 \\
(0.221)\end{array}$ & 666 & 2569 & $\begin{array}{r}0.00980 \\
(0.596)\end{array}$ & $\begin{array}{r}0.00008 \\
(0.398)\end{array}$ \\
\hline 20 & 45 & $\begin{array}{r}-0.07804 \\
(0.851)\end{array}$ & $\begin{array}{r}0.31731 \\
(0.976)\end{array}$ & $\begin{array}{r}0.39407 \\
(0.172)\end{array}$ & 884 & 2351 & $\begin{array}{r}0.01031 \\
(0.558)\end{array}$ & $\begin{array}{r}0.00008 \\
(0.523)\end{array}$ \\
\hline 40 & 28 & $\begin{array}{r}-0.02677 \\
(0.789)\end{array}$ & $\begin{array}{r}0.30023 \\
(0.963)\end{array}$ & $\begin{array}{r}0.46226 \\
(0.172)\end{array}$ & 1086 & 2149 & $\begin{array}{r}0.01040 \\
(0.645)\end{array}$ & $\begin{array}{r}0.00008 \\
(0.694)\end{array}$ \\
\hline 60 & 22 & $\begin{array}{r}-0.06328 \\
(0.836)\end{array}$ & $\begin{array}{r}0.27708 \\
(0.964)\end{array}$ & $\begin{array}{r}0.41460 \\
(0.178)\end{array}$ & 1319 & 1916 & $\begin{array}{r}0.01122 \\
(0.554)\end{array}$ & $\begin{array}{r}0.00008 \\
(0.906)\end{array}$ \\
\hline \multicolumn{9}{|c|}{ VDAXNEW 100 days } \\
\hline 10 & 89 & $\begin{array}{r}0.48069 \\
(0.188)\end{array}$ & $\begin{array}{r}0.35978 \\
(0.998)\end{array}$ & $\begin{array}{r}0.40235 \\
(0.040)\end{array}$ & 886 & 2534 & $\begin{array}{r}0.01190 \\
(0.237)\end{array}$ & $\begin{array}{r}0.00009 \\
(0.863)\end{array}$ \\
\hline 20 & 63 & $\begin{array}{r}0.40704 \\
(0.513)\end{array}$ & $\begin{array}{r}0.31378 \\
(0.999)\end{array}$ & $\begin{array}{r}0.33470 \\
(0.044)\end{array}$ & 1242 & 2178 & $\begin{array}{r}0.01200 \\
(0.298)\end{array}$ & $\begin{array}{r}0.00008 \\
(0.901)\end{array}$ \\
\hline 40 & 40 & $\begin{array}{r}0.64535 \\
(0.467)\end{array}$ & $\begin{array}{r}0.26061 \\
(0.999)\end{array}$ & $\begin{array}{r}0.56584 \\
(0.042)\end{array}$ & 1583 & 1837 & $\begin{array}{r}0.01264 \\
(0.297)\end{array}$ & $\begin{array}{r}0.00009 \\
(0.647)\end{array}$ \\
\hline 60 & 32 & $\begin{array}{r}0.86461 \\
(0.417)\end{array}$ & $\begin{array}{r}0.21961 \\
(1.000)\end{array}$ & $\begin{array}{r}0.76011 \\
(0.035)\end{array}$ & 1883 & 1537 & $\begin{array}{r}0.01255 \\
(0.427)\end{array}$ & $\begin{array}{r}0.00008 \\
(0.861)\end{array}$ \\
\hline \multicolumn{9}{|c|}{ VDAXNEW 200 days } \\
\hline 10 & 74 & $\begin{array}{r}0.14566 \\
(0.471)\end{array}$ & $\begin{array}{r}0.34942 \\
(0.999)\end{array}$ & $\begin{array}{r}0.04953 \\
(0.059)\end{array}$ & 740 & 2580 & $\begin{array}{r}0.01097 \\
(0.279)\end{array}$ & $\begin{array}{r}0.00009 \\
(0.153)\end{array}$ \\
\hline 20 & 48 & $\begin{array}{r}0.40995 \\
(0.185)\end{array}$ & $\begin{array}{r}0.32371 \\
(0.998)\end{array}$ & $\begin{array}{r}0.34011 \\
(0.047)\end{array}$ & 960 & 2360 & $\begin{array}{r}0.01104 \\
(0.350)\end{array}$ & $\begin{array}{r}0.00009 \\
(0.348)\end{array}$ \\
\hline 40 & 31 & $\begin{array}{r}0.33824 \\
(0.409)\end{array}$ & $\begin{array}{r}0.28250 \\
(0.999)\end{array}$ & $\begin{array}{r}0.26120 \\
(0.052)\end{array}$ & 1240 & 2080 & $\begin{array}{r}0.01184 \\
(0.342)\end{array}$ & $\begin{array}{r}0.00009 \\
(0.236)\end{array}$ \\
\hline 60 & 25 & $\begin{array}{r}0.27269 \\
(0.605)\end{array}$ & $\begin{array}{r}0.25239 \\
(0.999)\end{array}$ & $\begin{array}{r}0.17753 \\
(0.058)\end{array}$ & 1500 & 1820 & $\begin{array}{r}0.01215 \\
(0.367)\end{array}$ & $\begin{array}{r}0.00009 \\
(0.381)\end{array}$ \\
\hline \multicolumn{9}{|c|}{ VDAXNEW 300 days } \\
\hline 10 & 64 & $\begin{array}{r}0.03587 \\
(0.582)\end{array}$ & $\begin{array}{r}0.33969 \\
(0.997)\end{array}$ & $\begin{array}{r}-0.13016 \\
(0.079)\end{array}$ & 635 & 2585 & $\begin{array}{r}0.00945 \\
(0.475)\end{array}$ & $\begin{array}{r}0.00008 \\
(0.280)\end{array}$ \\
\hline 20 & 39 & $\begin{array}{r}0.47522 \\
(0.055)\end{array}$ & $\begin{array}{r}0.32693 \\
(0.995)\end{array}$ & $\begin{array}{r}0.34642 \\
(0.045)\end{array}$ & 765 & 2455 & $\begin{array}{r}0.00952 \\
(0.554)\end{array}$ & $\begin{array}{r}0.00008 \\
(0.528)\end{array}$ \\
\hline 40 & 23 & $\begin{array}{r}0.77748 \\
(0.022)\end{array}$ & $\begin{array}{r}0.31515 \\
(0.988)\end{array}$ & $\begin{array}{r}0.66890 \\
(0.032)\end{array}$ & 885 & 2335 & $\begin{array}{r}0.00985 \\
(0.600)\end{array}$ & $\begin{array}{r}0.00008 \\
(0.452)\end{array}$ \\
\hline 60 & 18 & $\begin{array}{r}0.75919 \\
(0.043)\end{array}$ & $\begin{array}{r}0.29178 \\
(0.994)\end{array}$ & $\begin{array}{r}0.63725 \\
(0.034)\end{array}$ & 1025 & 2195 & $\begin{array}{r}0.01003 \\
(0.661)\end{array}$ & $\begin{array}{r}0.00009 \\
(0.213)\end{array}$ \\
\hline
\end{tabular}

Note: HP is the holding period, Sig. is the number of signals, $\sum r_{\text {buy }}$ and $\sum r_{\text {sell }}$ are the returns on buy and sell days. $A E R$ are the adjusted excess returns, $N_{b u y}$ and $N_{\text {sell }}$ the number of buy and sell days. $\sigma_{b u y}$ and $\sigma_{\text {sell }}$ are the standard deviations on buy and sell days. Achieved significance levels are reported in parentheses. 
Table 4: Trading Results with VIX and VXN (US)

\begin{tabular}{|c|c|c|c|c|c|c|c|c|}
\hline $\mathrm{HP}$ & Sig. & $\sum r_{b u y}$ & $\sum r_{\text {sell }}$ & $A E R$ & $N_{\text {buy }}$ & $N_{\text {sell }}$ & $\sigma_{b u y}$ & $\sigma_{\text {sell }}$ \\
\hline \multicolumn{9}{|c|}{ VIX 100 days } \\
\hline 10 & 100 & $\begin{array}{r}0.06532 \\
(0.555)\end{array}$ & $\begin{array}{r}0.33219 \\
(1.000)\end{array}$ & $\begin{array}{r}-0.05005 \\
(0.167)\end{array}$ & 1000 & 2376 & $\begin{array}{r}0.00876 \\
(0.475)\end{array}$ & $\begin{array}{r}0.00009 \\
(0.191)\end{array}$ \\
\hline 20 & 67 & $\begin{array}{r}0.25460 \\
(0.334)\end{array}$ & $\begin{array}{r}0.29197 \\
(1.000)\end{array}$ & $\begin{array}{r}0.16501 \\
(0.126)\end{array}$ & 1340 & 2036 & $\begin{array}{r}0.00920 \\
(0.463)\end{array}$ & $\begin{array}{r}0.00009 \\
(0.229)\end{array}$ \\
\hline 40 & 41 & $\begin{array}{r}0.36297 \\
(0.361)\end{array}$ & $\begin{array}{r}0.25123 \\
(1.000)\end{array}$ & $\begin{array}{r}0.28465 \\
(0.120)\end{array}$ & 1640 & 1736 & $\begin{array}{r}0.00941 \\
(0.534)\end{array}$ & $\begin{array}{r}0.00009 \\
(0.225)\end{array}$ \\
\hline 60 & 32 & $\begin{array}{r}0.24274 \\
(0.624)\end{array}$ & $\begin{array}{r}0.23210 \\
(0.998)\end{array}$ & $\begin{array}{r}0.16329 \\
(0.150)\end{array}$ & 1919 & 1457 & $\begin{array}{r}0.00970 \\
(0.548)\end{array}$ & $\begin{array}{r}0.00008 \\
(0.887)\end{array}$ \\
\hline \multicolumn{9}{|c|}{ VIX 200 days } \\
\hline 10 & 82 & $\begin{array}{r}0.07370 \\
(0.425)\end{array}$ & $\begin{array}{r}0.33279 \\
(0.994)\end{array}$ & $\begin{array}{r}-0.00484 \\
(0.195)\end{array}$ & 820 & 2456 & $\begin{array}{r}0.00799 \\
(0.558)\end{array}$ & $\begin{array}{r}0.00009 \\
(0.053)\end{array}$ \\
\hline 20 & 54 & $\begin{array}{r}0.16112 \\
(0.327)\end{array}$ & $\begin{array}{r}0.30434 \\
(0.994)\end{array}$ & $\begin{array}{r}0.11013 \\
(0.174)\end{array}$ & 1080 & 2196 & $\begin{array}{r}0.00831 \\
(0.548)\end{array}$ & $\begin{array}{r}0.00009 \\
(0.112)\end{array}$ \\
\hline 40 & 35 & $\begin{array}{r}0.03333 \\
(0.690)\end{array}$ & $\begin{array}{r}0.25653 \\
(0.997)\end{array}$ & $\begin{array}{r}-0.02748 \\
(0.221)\end{array}$ & 1400 & 1876 & $\begin{array}{r}0.00877 \\
(0.579)\end{array}$ & $\begin{array}{r}0.00009 \\
(0.032)\end{array}$ \\
\hline 60 & 26 & $\begin{array}{r}0.19952 \\
(0.448)\end{array}$ & $\begin{array}{r}0.24841 \\
(0.995)\end{array}$ & $\begin{array}{r}0.14859 \\
(0.164)\end{array}$ & 1560 & 1716 & $\begin{array}{r}0.00891 \\
(0.617)\end{array}$ & $\begin{array}{r}0.00009 \\
(0.479)\end{array}$ \\
\hline \multicolumn{9}{|c|}{ VIX 300 days } \\
\hline 10 & 75 & $\begin{array}{r}0.03577 \\
(0.463)\end{array}$ & $\begin{array}{r}0.31547 \\
(0.994)\end{array}$ & $\begin{array}{r}-0.15415 \\
(0.214)\end{array}$ & 750 & 2426 & $\begin{array}{r}0.00738 \\
(0.641)\end{array}$ & $\begin{array}{r}0.00009 \\
(0.043)\end{array}$ \\
\hline 20 & 51 & $\begin{array}{r}0.19907 \\
(0.155)\end{array}$ & $\begin{array}{r}0.28141 \\
(0.998)\end{array}$ & $\begin{array}{r}0.02309 \\
(0.170)\end{array}$ & 1020 & 2156 & $\begin{array}{r}0.00750 \\
(0.685)\end{array}$ & $\begin{array}{r}0.00009 \\
(0.040)\end{array}$ \\
\hline 40 & 31 & $\begin{array}{r}0.21107 \\
(0.210)\end{array}$ & $\begin{array}{r}0.25734 \\
(0.997)\end{array}$ & $\begin{array}{r}0.05102 \\
(0.166)\end{array}$ & 1240 & 1936 & $\begin{array}{r}0.00782 \\
(0.717)\end{array}$ & $\begin{array}{r}0.00009 \\
(0.066)\end{array}$ \\
\hline 60 & 24 & $\begin{array}{r}0.34714 \\
(0.118)\end{array}$ & $\begin{array}{r}0.23900 \\
(0.997)\end{array}$ & $\begin{array}{r}0.18274 \\
(0.141)\end{array}$ & 1440 & 1736 & $\begin{array}{r}0.00825 \\
(0.692)\end{array}$ & $\begin{array}{r}0.00009 \\
(0.153)\end{array}$ \\
\hline \multicolumn{9}{|c|}{ VXN 100 days } \\
\hline 10 & 82 & $\begin{array}{r}0.29378 \\
(0.099)\end{array}$ & $\begin{array}{r}0.29937 \\
(1.000)\end{array}$ & $\begin{array}{r}-0.23374 \\
(0.082)\end{array}$ & 820 & 2282 & $\begin{array}{r}0.01313 \\
(0.405)\end{array}$ & $\begin{array}{r}0.00009 \\
(0.009)\end{array}$ \\
\hline 20 & 56 & $\begin{array}{r}0.76902 \\
(0.004)\end{array}$ & $\begin{array}{r}0.27450 \\
(1.000)\end{array}$ & $\begin{array}{c}0.26864 \\
(0.052)\end{array}$ & 1120 & 1982 & $\begin{array}{r}0.01293 \\
(0.437)\end{array}$ & $\begin{array}{r}0.00008 \\
(0.610)\end{array}$ \\
\hline 40 & 37 & $\begin{array}{r}0.67997 \\
(0.040)\end{array}$ & $\begin{array}{c}0.22244 \\
(1.000)\end{array}$ & $\begin{array}{r}0.16552 \\
(0.057)\end{array}$ & 1480 & 1622 & $\begin{array}{r}0.01353 \\
(0.419)\end{array}$ & $\begin{array}{r}0.00009 \\
(0.009)\end{array}$ \\
\hline 60 & 30 & $\begin{array}{r}0.20319 \\
(0.653)\end{array}$ & $\begin{array}{r}0.18427 \\
(1.000)\end{array}$ & $\begin{array}{r}-0.33542 \\
(0.119)\end{array}$ & 1799 & 1303 & $\begin{array}{r}0.01402 \\
(0.385)\end{array}$ & $\begin{array}{r}0.00009 \\
(0.050)\end{array}$ \\
\hline \multicolumn{9}{|c|}{ VXN 200 days } \\
\hline 10 & 86 & $\begin{array}{r}-0.29616 \\
(0.987)\end{array}$ & $\begin{array}{r}0.27270 \\
(0.997)\end{array}$ & $\begin{array}{r}-0.97640 \\
(0.214)\end{array}$ & 860 & 2142 & $\begin{array}{r}0.01233 \\
(0.289)\end{array}$ & $\begin{array}{r}0.00009 \\
(0.000)\end{array}$ \\
\hline 20 & 53 & $\begin{array}{r}0.09463 \\
(0.239)\end{array}$ & $\begin{array}{r}0.24879 \\
(0.998)\end{array}$ & $\begin{array}{r}-0.54353 \\
(0.130)\end{array}$ & 1060 & 1942 & $\begin{array}{r}0.01318 \\
(0.260)\end{array}$ & $\begin{array}{r}0.00009 \\
(0.000)\end{array}$ \\
\hline 40 & 34 & $\begin{array}{r}0.38386 \\
(0.033)\end{array}$ & $\begin{array}{r}0.20880 \\
(0.998)\end{array}$ & $\begin{array}{r}-0.25628 \\
(0.095)\end{array}$ & 1360 & 1642 & $\begin{array}{r}0.01296 \\
(0.297)\end{array}$ & $\begin{array}{r}0.00009 \\
(0.000)\end{array}$ \\
\hline 60 & 25 & $\begin{array}{r}0.30282 \\
(0.098)\end{array}$ & $\begin{array}{r}0.19646 \\
(0.998)\end{array}$ & $\begin{array}{r}-0.33166 \\
(0.105)\end{array}$ & 1500 & 1502 & $\begin{array}{r}0.01314 \\
(0.313)\end{array}$ & $\begin{array}{r}0.00009 \\
(0.000)\end{array}$ \\
\hline \multicolumn{9}{|c|}{ VXN 300 days } \\
\hline 10 & 71 & $\begin{array}{r}-0.06435 \\
(0.949)\end{array}$ & $\begin{array}{r}0.27711 \\
(0.999)\end{array}$ & $\begin{array}{r}-0.80913 \\
(0.183)\end{array}$ & 710 & 2192 & $\begin{array}{r}0.01050 \\
(0.245)\end{array}$ & $\begin{array}{r}0.00009 \\
(0.000)\end{array}$ \\
\hline 20 & 48 & $\begin{array}{r}0.42941 \\
(0.007)\end{array}$ & $\begin{array}{r}0.25361 \\
(0.999)\end{array}$ & $\begin{array}{r}-0.29287 \\
(0.114)\end{array}$ & 960 & 1942 & $\begin{array}{r}0.01190 \\
(0.199)\end{array}$ & $\begin{array}{r}0.00009 \\
(0.000)\end{array}$ \\
\hline 40 & 31 & $\begin{array}{r}0.65200 \\
(0.004)\end{array}$ & $\begin{array}{r}0.21505 \\
(0.999)\end{array}$ & $\begin{array}{r}-0.07484 \\
(0.085)\end{array}$ & 1225 & 1677 & $\begin{array}{r}0.01171 \\
(0.221)\end{array}$ & $\begin{array}{r}0.00009 \\
(0.000)\end{array}$ \\
\hline 60 & 22 & $\begin{array}{r}0.35055 \\
(0.035)\end{array}$ & $\begin{array}{r}0.21266 \\
(0.999)\end{array}$ & $\begin{array}{r}-0.36067 \\
(0.125)\end{array}$ & 1320 & 1582 & $\begin{array}{r}0.01234 \\
(0.200)\end{array}$ & $\begin{array}{r}0.00009 \\
(0.000)\end{array}$ \\
\hline
\end{tabular}

Note: HP is the holding period, Sig. is the number of signals, $\sum r_{\text {buy }}$ and $\sum r_{\text {sell }}$ are the returns on buy and sell days. $A E R$ are the adjusted excess returns, $N_{b u y}$ and $N_{\text {sell }}$ the number of buy and sell days. $\sigma_{b u y}$ and $\sigma_{\text {sell }}$ are the standard deviations on buy and sell days. Achieved significance levels are reported in parentheses. 
Table 5: Trading Results for VXJ (Japan)

\begin{tabular}{|c|c|c|c|c|c|c|c|c|}
\hline $\mathrm{HP}$ & Sig. & $\sum r_{b u y}$ & $\sum r_{\text {sell }}$ & $A E R$ & $N_{\text {buy }}$ & $N_{\text {sell }}$ & $\sigma_{\text {buy }}$ & $\sigma_{\text {sell }}$ \\
\hline \multicolumn{9}{|c|}{ VXJ 100 days } \\
\hline 10 & 81 & $\begin{array}{r}-0.10091 \\
(0.946)\end{array}$ & $\begin{array}{r}0.35358 \\
(0.073)\end{array}$ & $\begin{array}{r}0.19682 \\
(0.042)\end{array}$ & 810 & 2489 & $\begin{array}{r}0.01173 \\
(0.931)\end{array}$ & $\begin{array}{r}0.00009 \\
(0.572)\end{array}$ \\
\hline 20 & 55 & $\begin{array}{r}-0.16216 \\
(0.954)\end{array}$ & $\begin{array}{r}0.31923 \\
(0.092)\end{array}$ & $\begin{array}{r}0.15322 \\
(0.063)\end{array}$ & 1084 & 2215 & $\begin{array}{r}0.01275 \\
(0.814)\end{array}$ & $\begin{array}{r}0.00009 \\
(0.549)\end{array}$ \\
\hline 40 & 36 & $\begin{array}{r}-0.20827 \\
(0.959)\end{array}$ & $\begin{array}{r}0.27141 \\
(0.134)\end{array}$ & $\begin{array}{r}0.09729 \\
(0.082)\end{array}$ & 1425 & 1874 & $\begin{array}{r}0.01357 \\
(0.719)\end{array}$ & $\begin{array}{r}0.00009 \\
(0.384)\end{array}$ \\
\hline 60 & 28 & $\begin{array}{r}-0.49353 \\
(0.976)\end{array}$ & $\begin{array}{r}0.24333 \\
(0.137)\end{array}$ & $\begin{array}{r}-0.20005 \\
(0.183)\end{array}$ & 1645 & 1654 & $\begin{array}{r}0.01493 \\
(0.484)\end{array}$ & $\begin{array}{r}0.00009 \\
(0.521)\end{array}$ \\
\hline \multicolumn{9}{|c|}{ VXJ 200 days } \\
\hline 10 & 70 & $\begin{array}{r}0.34507 \\
(0.748)\end{array}$ & $\begin{array}{r}0.33854 \\
(0.125)\end{array}$ & $\begin{array}{r}0.57616 \\
(0.028)\end{array}$ & 696 & 2503 & $\begin{array}{r}0.01050 \\
(1.000)\end{array}$ & $\begin{array}{r}0.00009 \\
(0.370)\end{array}$ \\
\hline 20 & 43 & $\begin{array}{r}0.19691 \\
(0.854)\end{array}$ & $\begin{array}{r}0.32158 \\
(0.104)\end{array}$ & $\begin{array}{r}0.46506 \\
(0.036)\end{array}$ & 846 & 2353 & $\begin{array}{r}0.01107 \\
(0.995)\end{array}$ & $\begin{array}{r}0.00009 \\
(0.412)\end{array}$ \\
\hline 40 & 27 & $\begin{array}{r}0.05648 \\
(0.915)\end{array}$ & $\begin{array}{r}0.29093 \\
(0.139)\end{array}$ & $\begin{array}{r}0.32596 \\
(0.058)\end{array}$ & 1046 & 2153 & $\begin{array}{r}0.01315 \\
(0.776)\end{array}$ & $\begin{array}{r}0.00009 \\
(0.305)\end{array}$ \\
\hline 60 & 24 & $\begin{array}{r}-0.11449 \\
(0.955)\end{array}$ & $\begin{array}{r}0.24872 \\
(0.273)\end{array}$ & $\begin{array}{r}0.11878 \\
(0.092)\end{array}$ & 1386 & 1813 & $\begin{array}{r}0.01502 \\
(0.455)\end{array}$ & $\begin{array}{r}0.00009 \\
(0.300)\end{array}$ \\
\hline \multicolumn{9}{|c|}{ VXJ 300 days } \\
\hline 10 & 59 & $\begin{array}{r}0.18509 \\
(0.795)\end{array}$ & $\begin{array}{r}0.32644 \\
(0.140)\end{array}$ & $\begin{array}{r}0.23071 \\
(0.057)\end{array}$ & 590 & 2509 & $\begin{array}{r}0.01083 \\
(0.989)\end{array}$ & $\begin{array}{r}0.00008 \\
(0.361)\end{array}$ \\
\hline 20 & 36 & $\begin{array}{r}0.16901 \\
(0.832)\end{array}$ & $\begin{array}{r}0.30917 \\
(0.145)\end{array}$ & $\begin{array}{r}0.24336 \\
(0.065)\end{array}$ & 720 & 2379 & $\begin{array}{r}0.01213 \\
(0.927)\end{array}$ & $\begin{array}{r}0.00009 \\
(0.306)\end{array}$ \\
\hline 40 & 22 & $\begin{array}{r}0.31102 \\
(0.782)\end{array}$ & $\begin{array}{r}0.28591 \\
(0.169)\end{array}$ & $\begin{array}{r}0.39011 \\
(0.052)\end{array}$ & 880 & 2219 & $\begin{array}{r}0.01227 \\
(0.946)\end{array}$ & $\begin{array}{r}0.00009 \\
(0.253)\end{array}$ \\
\hline 60 & 17 & $\begin{array}{r}0.43178 \\
(0.757) \\
\end{array}$ & $\begin{array}{r}0.26792 \\
(0.189) \\
\end{array}$ & $\begin{array}{r}0.50288 \\
(0.048) \\
\end{array}$ & 1020 & 2079 & $\begin{array}{r}0.01144 \\
(0.996) \\
\end{array}$ & $\begin{array}{r}0.00009 \\
(0.201) \\
\end{array}$ \\
\hline
\end{tabular}

Note: HP is the holding period, Sig. is the number of signals, $\sum r_{\text {buy }}$ and $\sum r_{\text {sell }}$ are the returns on buy and sell days. $A E R$ are the adjusted excess returns, $N_{b u y}$ and $N_{\text {sell }}$ the number of buy and sell days. $\sigma_{b u y}$ and $\sigma_{\text {sell }}$ are the standard deviations on buy and sell days. Achieved significance levels are reported in parentheses. 